\title{
Barley cultivar MN 698, high malting quality for the state of Rio Grande do Sul
}

\author{
Cultivar MN 698, cevada de alta qualidade malteira para o estado do Rio Grande do Sul
}

\author{
Eduardo Caierão ${ }^{1}$ Alessandro Luis Sperotto ${ }^{2}$
}

\begin{abstract}
MN 698 is a new cultivar developed by AmBev ABSTRACT that resulted from a cross between the cultivars MN 599 and $M N$ 635. MN 698 shows a grain yield potential higher than $4 t$ $\mathrm{ha}^{-1}$, has early cycle and is moderately resistant to lodging. Its spike is uniform and produces around 20 grains welldistributed. MN 698 shows a medium tillering capacity (two to three per plant), and is characterized by the presence of anthocyanin in the culm basis, arists, and glumes. It is the national cultivar with the highest quality and represents an important advance for this cereal in Brazil, combining interests of both the producer and the industrial sector.
\end{abstract}

Key words: Hordeum vulgare, cereal breeding, barley genetic.

\section{RESUMO}

A cultivar MN 698, desenvolvida pela AmBev é resultado do cruzamento entre as cultivares MN 599 e MN 635.

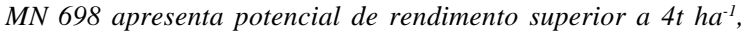
possui ciclo precoce e moderada resistência ao acamamento. A espiga é uniforme e produz em torno de 20 grãos bem distribuídos. MN 698 demonstra capacidade de afilhamento mediana (dois a três por planta) e caracteriza-se pela presença de antocianina na base do colmo, aristas e glumas. É a cultivar nacional de melhor qualidade e representa importante avanço para este cereal no Brasil, combinando interesses de produtores e da indústria do setor.

Palavras-chave: Hordeum vulgare, melhoramento de cereais, genética da cevada.
Barley spreading occurs by deals between producers and malting industries. Thus, there are a reliable estimative this cereal production year by year. The barley area in Rio Grande do Sul State changes as according to climatic conditions, price policies and context of other commodities, such as wheat and soybean. In 2004, aproximately 80,000ha of this cereal were cultivated in Rio Grande do Sul State, being 40,000ha seeded with MN 698 cultivar (50\% of expanded area) in the State of Rio Grande do Sul. Other cultivars cultivated are BRS 195 (40\% of area) and E 127, MN 684, MN 610 and other lines, representing $10 \%$ of area. The cultivated area of MN 698 represents about 80,000 t of barley that will not be imported, favoring the production chain of this cereal in Brazil.

The genetic improvement program carried out by the AmBev aims at developing new barley cultivars to uphold the supply of this cereal in Brazil. Therefore, it is focused on identifying hight-yielding cultivars in combination with a high-malting quality. MN 698 is a barley cultivar developed by AmBev, after six years (1993 to 1998) of qualitative and quantitative evaluations under different environmental conditions

\footnotetext{
${ }^{1}$ Empresa Brasileira de Pesquisa Agropecuária (Embrapa). Rodovia BR 285, km 174 - Cx. P.451, CEP: 99001-970, Passo Fundo, RS, Brasil. E-mail: caierao@cnpt.embrapa.br. Autor para correspondência.

${ }^{2}$ Cia. Brasileira de Bebidas (AmBev). Av. Voluntários da Pátria, 2619, bairro Navegantes, CEP: 90230-011. Porto Alegre, RS, Brasil. E-mail: mnals@ambev.com.br.
} 
in the three states of the southern region of Brazil. MN 698 represents a noteworthy genetic progress in the production of barley, for it gathers favorable phenotypes and a number of important agronomic traits. Consequently, malting industries are able to reduce the percentage of imported barley in their blends, thus becoming more competitive. The objective of this work was to provide information on the performance of this novel cultivar to the scientific community.

MN 698 was the result of a single cross carried out by the Cia. Cervejaria Brahma, in 1986, between cultivars MN 599 and MN 635. The pedigree of this cultivar combines genetic characteristics of good agronomic and qualitative traits from genotypes of the companies Embrapa and Brahma (Figure 1). The segregant generations up to homozygosity were conducted at the Estação Experimental of Encruzilhada do Sul. Up to $\mathrm{F}_{4}$ generation the bulk method was used. In $F_{5}$ and $F_{6}$ generations, the pedigree method was followed. This line was evaluated in a preliminary trial in 1993 and in a regional trial in 1994 and 1995, and then for its Cultivation and Use Value in 1996, 1997, and 1998. In 1999 and 2000, the cultivar was qualitatively evaluated at industrial scale (condition for the release and acceptance by the beer industries) in the brewery Maltaria Navegantes, in Porto Alegre, Brazil. The malt produced during the malting process was forwarded to the Centro de Desenvolvimento Tecnológico (CDT), in Guarulhos, São Paulo, for a sensorial and organoleptic evaluation of the beer in 2001. MN 698 was registered for cultivation in the State of Rio Grande do Sul. Data on the evaluation trials and registration at the Ministério da Agricultura are shown in the abstracts of the Comissão Brasileira de Pesquisa de Cevada (SPEROTTO, 1997; MINELLA et al., 1998; SPEROTTO, 1999).

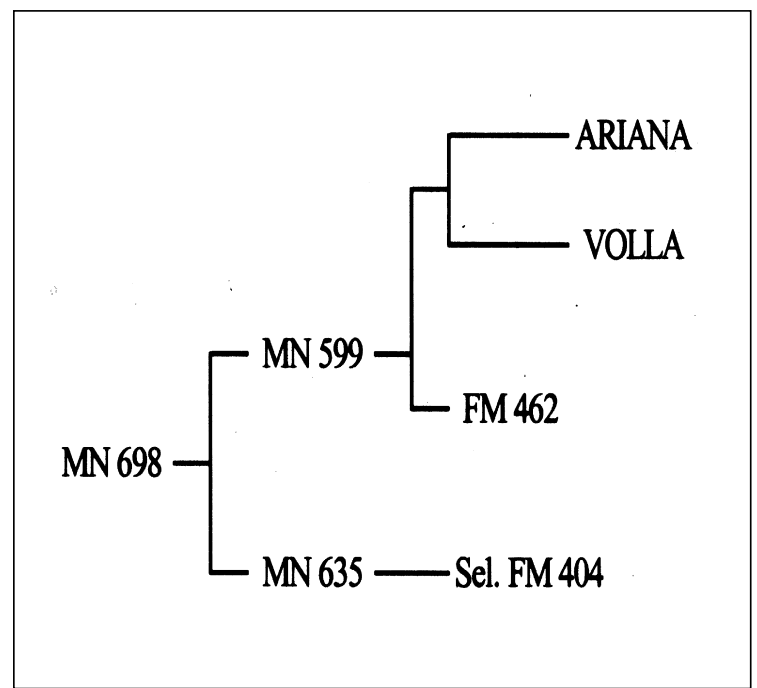

Figure 1 - Pedigree of the cultivar MN 698

MN 698 shows a grain yield potential higher than $4 \mathrm{t} \mathrm{ha}^{-1}$. Its average yield is close to $3.5 \mathrm{t} \mathrm{ha}^{-1}$. Over the three years of evaluation, its mean grain yield exceeded the control BR 2 by $6.27,14.4$, and $1.63 \%$, respectively. In the evaluation reflecting the mean of 21 environments, in three years, MN 698 was superior to BR 2 by $7.40 \%$ (Table 1). The cultivar presents an average grain over $2.5 \mathrm{~mm}$ percentage around $95 \%$ (Table 2), with a low percentage of tertiary quality (below $2.2 \mathrm{~mm}$ ), what confers a high profitability to producers. Concerning the quality, all tests carried out during the experimental stage ( $500 \mathrm{~g}$ of barley) and microbrewing ( $800 \mathrm{~kg}$ of barley) certify its brewing pattern. Its extract and protein content, diastatic power, and friability meet industry especifications (Table 2).

Cultivar MN 698 is indicated for the State of Rio Grande do Sul. It has a semi-upright growth

Table 1 - Grain yield $\left(\mathrm{kg} \mathrm{ha}^{-1}\right)$ of the cultivar MN 698 in different environments compared to the check, cultivar BR 2

\begin{tabular}{|c|c|c|c|c|c|c|}
\hline \multirow{2}{*}{ Environment } & \multicolumn{2}{|c|}{1998} & \multicolumn{2}{|c|}{1997} & \multicolumn{2}{|c|}{1996} \\
\hline & MN 698 & BR $2(\mathrm{C})$ & MN 698 & BR $2(\mathrm{C})$ & MN 698 & BR $2(\mathrm{C})$ \\
\hline Passo Fundo & 3,849 & 3,730 & 4,227 & 3,678 & 4,000 & 3,778 \\
\hline Selbach & 2,924 & 3,092 & 1,895 & 1,634 & 3,891 & 3,634 \\
\hline Vacaria & 3,433 & 3,518 & 3,865 & 3,059 & 2,647 & 2,655 \\
\hline Sananduva & 3,912 & 3,818 & 4,709 & 3,983 & 1,297 & 1,380 \\
\hline Encruzilhada do Sul & 3,012 & 2,587 & 3,079 & 2,814 & 2,832 & 2,033 \\
\hline Cachoeira do Sul & 3,391 & 3,352 & 3,702 & 3,502 & 1,898 & 2,136 \\
\hline Piratini & 4,400 & 4,423 & 5,055 & 4,506 & 3,500 & 3,264 \\
\hline General mean & 3,560 & 3,503 & 3,790 & 3,311 & 2,866 & 2,697 \\
\hline
\end{tabular}

$\mathrm{C}=$ Control. 
Table 2 - Industrial quality of the cultivar MN 698 based upon industrial process of the brewery Maltaria Navegantes, of Porto Alegre, Brazil.

\begin{tabular}{|c|c|c|c|}
\hline Character & Unit & MN 698 & Specification \\
\hline $\begin{array}{l}\text { Kernel } \\
\text { plumpness* }\end{array}$ & $\%$ & 96.0 & - \\
\hline Protein content & $\%$ & 11.8 & From 10.5 to 12.5 \\
\hline Extract & $\%$ & 81.4 & Minimum 80.5 \\
\hline Diastatic power & $\mathrm{Wk}$ & 240.0 & Minimum 220 \\
\hline B-glucan & $\operatorname{mg~} 100 \mathrm{~g}^{-1}$ & 140.0 & Maximum 180 \\
\hline Friability & $\%$ & 82.0 & Minimum 75 \\
\hline
\end{tabular}

* Means of 21 environments.

habit and is susceptible to soil acidity. Its vegetative cycle is averagely as long as 90 days, with approximately 140 days from emergence to maturation. As its plant architecture ensures a moderate lodging resistance, qualitative loss occurs only under highly adverse conditions (heavy, rain, low light incidence, and strong wind). The spike is uniform and produces around 20 grains well-distributed. MN 698 shows a medium tillering capacity (two to three per plant). MN 698 is characterized by the presence of anthocyanin in the culm basis, arists, and glumes. It is intermediately tall $(70-80 \mathrm{~cm})$ and stands out for its remarkable adaptive capacity to the different regions of the State of Rio Grande do Sul. As to diseases, cultivar MN 698 presents susceptibility to Blumeria graminis f. sp. hordei, Puccinia hordei, Pyrenophora teres, Bipolaris sorokiniana, and Fusarioum sp (REUNIÃO, 2005). AmBev is in charge of the genetic seed of cultivar MN 698. Seed trade is supervised by the company itself, as well as by cereal grain producers and cooperatives supplying barley in Brazil.

\section{REFERENCES}

SPEROTTO, A. Ensaios finais de cevada conduzidos na região sul, em 1996. In: REUNIÃO ANUAL DE PESQUISA DE CEVADA, 17., 1997, Passo Fundo, RS. Anais... Passo Fundo: Embrapa Trigo, 1997. p.234-241.

MINELLA, E. et al. Ensaio final de cevada 1997: resultados obtidos no planalto do Rio Grande do Sul. In: REUNIÃO ANUAL DE PESQUISA DE CEVADA, 18., 1998, Passo Fundo, RS. Anais.... Passo Fundo: Embrapa Trigo, 1998. p.199-205.

SPEROTTO, A. Ensaios finais de cevada conduzidos na região sul, em 1998. In: REUNIÃO ANUAL DE PESQUISA DE CEVADA, 19., 1999, Passo Fundo, RS. Anais... Passo Fundo: Embrapa Trigo, 1999. p.133-144.

REUNIÃO ANUAL DE PESQUISA DE CEVADA. Indicações técnicas para a produção de cevada cervejeira nas safras 2005 e 2006. Passo Fundo: Embrapa Trigo - Sistemas de Produção, 2, 2005. 102p. 